WSRC-RP-99-00253, Rev. 0

\title{
An Evaluation of Liquidus Temperature as a Function of Waste Loading for a Tank 42 "Sludge Only"/Frit 200 Flowsheet
}

by

D. Peeler

Westinghouse Savannah River Company Savannah River Site

Aiken, South Carolina 29808

D. P. Lambert

J. R. Zamecnik

T. B. Edwards

DOE Contract No. DE-AC09-96SR18500

This paper was prepared in connection with work done under the above contract number with the U. S. Department of Energy. By acceptance of this paper, the publisher and/or recipient acknowledges the U.S. Government's right to retain a nonexclusive, royalty-free license in and to any copyright covering this paper, along with the right to reproduce and to authorize others to reproduce all or part of the copyrighted paper. 


\section{DISCLAIMER}

This report was prepared as an account of work sponsored by an agency of the United States Government. Neither the United States Government nor any agency thereof, nor any of their employees, makes any warranty, express or implied, or assumes any legal liability or responsibility for the accuracy, completeness, or usefulness of any information, apparatus, product, or process disclosed, or represents that its use would not infringe privately owned rights. Reference herein to any specific commercial product, process, or service by trade name, trademark, manufacturer, or otherwise does not necessarily constitute or imply its endorsement, recommendation, or favoring by the United States Government or any agency thereof. The views and opinions of authors expressed herein do not necessarily state or reflect those of the United States Government or any agency thereof.

This report has been reproduced directly from the best available copy.

Available to DOE and DOE contractors from the Office of Scientific and Technical Information, P. O. Box 62, Oak Ridge, TN 37831; prices available from (423) 576-8401.

Available to the public from the National Technical Information Service, U. S. Department of Commerce, 5285 Port Royal Road, Springfield, VA 22161. 
March 1, 1999

\title{
An Evaluation of Liquidus Temperature as a Function of Waste Loading for a Tank 42 "Sludge Only" / Frit 200 Flowsheet
}

\author{
Technical Task \& QA Plan
}

D.K. Peeler, D.P. Lambert, J.R. Zamecnik, W.E. Daniel, and T.B. Edwards

Westinghouse Savannah River Company

Savannah River Technology Center

Tanks Focus Area (TFA)

Increased Waste Loading Task (SR1-6-WT-31)

Subtask A

Westinghouse Savannah River Company

Savannah River Site

Aiken, SC 29808 


\begin{tabular}{|c|c|c|c|}
\hline $\begin{array}{l}\text { Task Lead: } \\
\text { D.K. Peeler }\end{array}$ & Signature yed yoled & $\begin{array}{l}\text { Organization: } \\
\text { ITS }\end{array}$ & $\begin{array}{l}\text { Date: } \\
3 / 16 / 99\end{array}$ \\
\hline $\begin{array}{l}\text { Task Lead: } \\
\text { D.P. Lambert }\end{array}$ & Signature: & $\begin{array}{l}\text { Organization: } \\
\text { ITS }\end{array}$ & Date: $1-24-99$ \\
\hline $\begin{array}{l}\text { Task Lead: } \\
\text { J.R. Zamencik }\end{array}$ & Signatyre: & $\begin{array}{l}\text { Organization: } \\
\text { ITS }\end{array}$ & Date: $3-23-99$ \\
\hline $\begin{array}{l}\text { Task Lead: } \\
\text { W.E. Daniel }\end{array}$ & Signature & $\begin{array}{l}\text { Organization: } \\
\text { ITS }\end{array}$ & $\begin{array}{l}\text { Date: } \\
3-24-99\end{array}$ \\
\hline $\begin{array}{l}\text { Task Lead: } \\
\text { T.B. Edwards }\end{array}$ & Signare: B Clalade & $\begin{array}{l}\text { Organization: } \\
\text { SCS }\end{array}$ & $\begin{array}{l}\text { Date: } \\
3 / 17 / 99\end{array}$ \\
\hline $\begin{array}{l}\text { Customer: } \\
\text { E.W. Holtzscheiter }\end{array}$ & Signature: & $\begin{array}{l}\text { Organization: } \\
\text { TFA } \\
\end{array}$ & $\begin{array}{l}\text { Date: } \\
4-8-97\end{array}$ \\
\hline $\begin{array}{l}\text { Technical Reviewer: } \\
\text { S.L. Marra }\end{array}$ & $\begin{array}{l}\text { Signature: } \\
\text { Shavon o. mane }\end{array}$ & $\begin{array}{l}\text { Organization: } \\
\text { ITS } \\
\end{array}$ & $\begin{array}{l}\text { Date: } \\
3 / 25 / 99\end{array}$ \\
\hline $\begin{array}{l}\text { Technical Reviewer: } \\
\text { C.M. Jantzen }\end{array}$ & Signature: M M lantur & $\begin{array}{l}\text { Organization: } \\
\text { ITS }\end{array}$ & $4 / 4 / 99$ \\
\hline $\begin{array}{l}\text { Level } 4 \text { Manager: } \\
\text { D.A. Crowley }\end{array}$ & Sistarido & $\begin{array}{l}\text { Organization: } \\
\text { ITS }\end{array}$ & $\begin{array}{l}\text { Date: } \\
3 / 23 / 99\end{array}$ \\
\hline $\begin{array}{l}\text { SRTC QA } \\
\text { T.K. Snyder }\end{array}$ & Signature:/ & $\begin{array}{l}\text { Organization: } \\
\text { ITS }\end{array}$ & $3 / 24 / 99$ \\
\hline
\end{tabular}

\section{Distribution:}

E.W. Holtzscheiter, 773-A

C.R. Goetzman, 773-A

D.A. Crowley, 773-43A

L.F. Landon, 704-1T

S.L. Marra, 704-T

T.B. Edwards, 773-42A

J.R. Zamencik, 773-41A

D.P. Lambert, 704-1T

W.E. Daniel, 704-1T

R.F. Schumacher, 773-43A

C.M. Jantzen, 773-A

K.G. Brown, 704-1T

A.D. Cozzi, 773-43A

I.A. Reamer, 773-A

D.R. Best, 773-41A

E.M. Frickey, 773-43A

T.K. Snyder, 704-T

R. C. Tuckfield, 773-42A 
Immobilization Technology Section

WSRC-RP-99-000253

Savannah River Technology Center

Rev. 0

Task Technical \& QA Plan

Page 3

\begin{tabular}{|c|l|l|l|}
\hline $\begin{array}{c}\text { Revision } \\
\text { Number: }\end{array}$ & Page Number: & Date: & Revision: \\
0 & & & \\
\hline
\end{tabular}




\section{INTRODUCTION}

The waste glass produced in the SRS Defense Waste Processing Facility (DWPF) process must comply with Waste Acceptance Product Specifications (WAPS) and process control requirements by demonstrating, to a high degree of confidence, that melter feed will produce glass satisfying all quality and processing requirements. Compliance methods require that uncertainties associated - with sample analysis and models used to estimate properties (which cannot be measured in situ) from feed and glass composition (which can be measured) be calculated and that sufficient allowance is made for all uncertainties when controlling feed composition. Thus property prediction models are essential to any compliance strategy.

Historically, high level waste ( $\mathrm{HLW}$ ) glass formulation focused on achieving a safe and reliable vitrification process that would produce a glass that demonstrably satisfied the appropriate WAPS; existing data were developed to meet this conservative approach. Property-composition relationships were developed around site-specific wastes and processes over a range of waste loadings. These relationships are typically modeled and the uncertainties of model predictions addressed such that the risk of a process upset or the likelihood of producing a product out of compliance is extremely low (i.e., at a $\geq 95 \%$ confidence level). Figure 1 is an example of the Process Acceptable Window (PrAR) defined for DWPF. The PrAR identifies the composition window resulting from possible blends of frit, sludge, and PHA that ensure both process (viscosity and liquidus temperature) and product performance (durability and homogeneity) criteria are satisfied. The PrAR includes all sources of error (e.g., property prediction uncertainty, experimental error, etc.) and thus is the largest window of opportunity available for processing.

One of the existing DWPF property models (liquidus temperature $\left(T_{L}\right)$ ) has large prediction uncertainties associated with it (largely due to sparseness of data); these uncertainties can directiy restrict the achievable waste loading and increase immobilization costs. For example, the current DWPF liquidus temperature $\left(T_{L}\right)$ constraint is based on a limited data set (i.e., 22 glasses) which was not optimally designed. The existing DWPF liquidus temperature model has a large prediction uncertainty, and its application has limited waste loadings for DWPF. Expanding the liquidus temperature database via designed statistical studies may lead to a reduction in model uncertainty thus increasing the operational window for DWPF. The direct result would be higher achievable waste loadings and a tangible cost savings.

Through the Tanks Focus Area (TFA), glasses were statistically designed by the Savannah River Technology Center (SRTC) to provide adequate coverage of anticipated glass compositions to be processed in the DWPF. These glasses were prepared and liquidus temperatures were measured by Pacific Northwest National Laboratory (PNNL) in FY'97 and '98. Using SRS co-funding, these glasses were analyzed by SRTC for whole element chemistry, and the resulting liquidus temperature versus composition data is being examined to attempt to improve the prediction model used for DWPF process control via a reduction in model uncertainty. With such an improved prediction, it is anticipated that a $1 \%$ increase in waste loading may be achieved. In general, TFA is not supporting model development at any site-only necessary data generation; model development will be the responsibility of each site or a privatization vendor if they choose to use the data. 


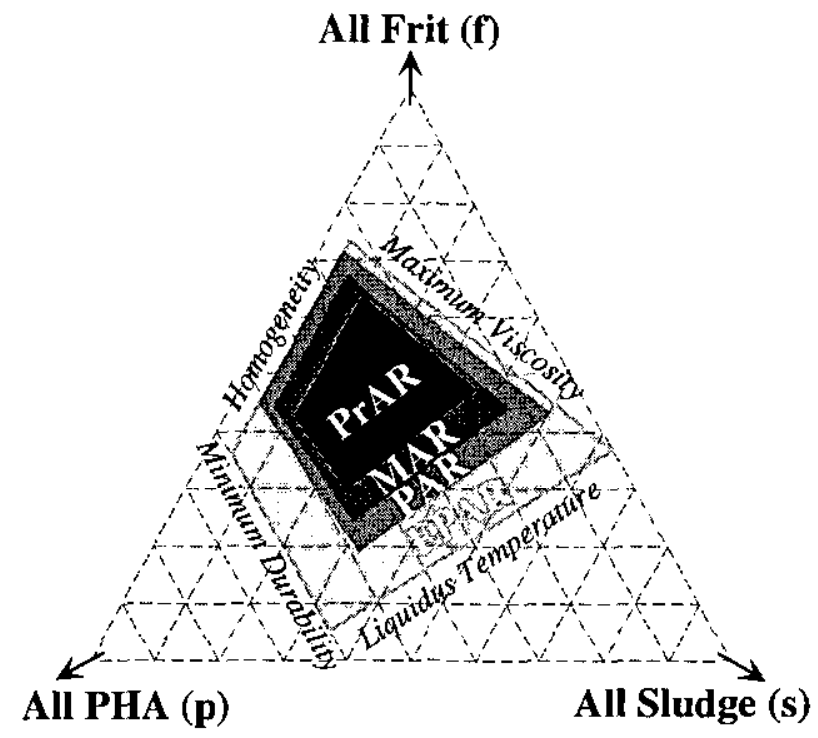

Figure 1. The PrAR as Defined by the Primary Processing and Product Performance Properties.

\section{A. Task Definition}

As indicated, the primary property most likely to restrict HLW loading in borosilicate glass and thus facility operation is liquidus temperature. As described above, a separate effort is underway to address the modeling aspects of this overall TFA task. In support of this effort, a scaled melter run is scheduled during FY' 99 as a means of "validating" predictions of increased waste loading. A draft melter run test plan was issued in November 1998 which outlined the proposed approach.[1] That plan identified a series of laboratory scale tests which would be performed prior to the melter run. The objective of the laboratory scale tests is to provide a technical basis on which to base the scaled melter run. That is, the primary outcome of the laboratory crucible scale tests will be the identification of the waste loading (single sludge composition) to be used in the scale melter test.

This document outlines the proposed work scope associated with the small laboratory crucible scale tests. Initially this task was defined to be a "validation" of the improved models coupling the newly acquired data with the limited existing data set. However, technical issues with the data generation and subsequent model efforts have delayed the issuance of these new models. Therefore, this subtask has changed its focus slightly. The models, with the associated and appropriate error terms factored in, will not be utilized to target the waste loading for the scaled melter run. ${ }^{\mathbf{a}}$ However, the scaled melter run will be performed at a waste loading based on the results of a limited series of laboratory scale tests and subsequent glass characterization activities. In essence, the melter run will attempt to provide sufficient evidence that higher waste loadings (i.e., at least $1 \mathrm{wt} \%$ increase) are or are not feasible for a given Tank 42 "sludge only" flowsheet. If proven feasible, additional liquidus temperature data may be required to reduce the associated uncertainties prior to

\footnotetext{
${ }^{a}$ If the improved models are available prior to the melter run, the targeted waste loading may be based on both the crucible scale results and model predictions.
} 
implementation in the DWPF if the data gathered by the TFA in FY'98 is insufficient to reduce the errors adequately to allow the desired increase in waste loading. It is important to note that this task is addressing only one waste stream (i.e., Tank 42 "sludge only"). It is not the intent of this task to evaluate all potential feed streams that the DWPF may encounter; therefore the results of this study should be used accordingly.

The Technical Task Plan (TTP SR1-6-WT-31, Subtask A, Increased Waste Loading) outlining the needs of the TFA describes the basis for which this Task Plan has been developed.[2]

\section{B. Customer/Requester}

The customer for this effort is Dr. E.W. Holtzscheiter, the Tanks Focus Area (TFA) Technical Integration Manager (TIM) for the Immobilization Task.

\section{Task Responsibilities}

D.A. Crowley assigned this task to D.K. Peeler who has the responsibility of overseeing the completion of this work. D.K. Peeler will be the task leader and is responsible for the proper administration and completion of this task according to 1Q, QAP 2-3, Control of Research and Development Activities [3] and the SRTC Conduct of Research and Development [4]. Dr. Peeler will oversee all analytical requirements including chemical composition and property measurements associated with this task. The final summary report will be included in this responsibility. Dr. R. Schulz has the responsibility of measuring $T_{L}$ of each glass for SRTC.

D.P. Lambert and W.E. Daniel have been assigned the responsibilities associated with the feed preparation (both for the laboratory scale test and the melter run) and fabrication of the laboratory scale melts. Mr. Lambert is responsible for the proper administration and completion of this subtask according to 1Q, QAP 2-3, Control of Research and Development Activities [3] and the SRTC Conduct of Research and Development [4].

R.F. Schumacher has been assigned the responsibilities associated with splitting the calcined feed and supplying the appropriate samples for chemical analysis. Dr. Schumacher is responsible for the proper administration and completion of this subtask according to 1Q, QAP 2-3, Control of Research and Development Activities [3] and the SRTC Conduct of Research and Development [4].

T.B. Edwards has the responsibility for developing the test matrix for this study as well as performing statistical analyses of the data. Dr. Edwards will also provide analytical plans to support both compositional analysis and property measurements as required.

T.K. Snyder and the SRTC Quality Assurance Department will provide QA support.

\section{Task Deliverables}

The result of this task will be one or more reports which provide the results of the laboratory scale tests.

\section{E. Technical Reviewers}

C.M. Jantzen and S.L. Marra will technically review all reports developed during this task prior to issuance. 


\section{TASK ACCEPTANCE CRITERIA}

Acceptance of the final report by the customer as noted by the approval signature will indicate that the task has met customer requirements.

\section{TASK ACTIVITIES}

The following laboratory scale activities are proposed to support the scaled melter run. These activities identify the specific DWPF flow sheet to be evaluated, feed preparation tasks and analysis, melting conditions of the glass, and post melting tests (including composition analysis and various property measurements). The task activities can be divided into a number of key elements. For quality assurance purposes, the following controls will be in place and enforced:

\subsection{DWPF Feed Preparation}

This task will utilize a Tank 42 "sludge only" simulant / Frit 200 flow sheet. The feed will contain the appropriate noble metal concentrations as identified in the material balance calculations and both formic and nitric acid. Mercury $(\mathrm{Hg})$ will be excluded (this should have no effect on the property of interest).

The feed, a calcined SRAT product will be prepared by adding formic acid and nitric acid to a Tank 42 sludge simulant to target a predicted glass redox of 0.1 to $0.2 \mathrm{Fe}^{+2} / \mathrm{Fe}_{\text {total }}$. Once the feed is calcined, redox issues associated with the nitric and formic acids will not be accounted for in the vitrification process. To allow the waste loading to vary, only a DWPF SRAT product will be produced. This will allow the addition of various amounts of Frit 200 to vary the waste loading in the glass.

The following are specific subtasks that will be performed to produce the feed:

- Sample the sludge carboy. Note the sample will not be analyzed but will be retained as an archived sample.

- Calculate the noble metal and acid addition necessary for addition to the sludge.

- Add noble metals to carboy.

- Add formic acid to carboy.

- Add nitric acid to carboy.

The furnace temperature will be held at $90^{\circ} \mathrm{C}$ for 60 minutes to allow the normal SRAT reactions to proceed prior to calcination. It should be noted that modifications to the current calcine procedure will be made to handle the slurry prior to the reactions. The SRAT product will be calcined in an open platinum crucible at $900^{\circ} \mathrm{C}$ to eliminate any potential offgas species (e.g., $\mathrm{NO}_{\mathrm{x}}$ ). Complete calcination will increase the likelihood of obtaining targeted waste loadings. This resulting calcined SRAT product will be utilized in the laboratory scale tests. The calcined product will be ground in a tungsten carbide or ceramic mortar or automated grinder system to aid mixing and to produce a more homogeneous product (without introducing contamination which could have an effect on $T_{L}$ ).

It is recognized that calcining the feed will impact the evaluation of redox issues on both melter processing (e.g., foaming) and potential redox issues on liquidus temperature. However, calcination may provide a more accurate means to ensure that targeted waste loadings are achieved (see discussion in next section) which is the primary driver for these tests. If deemed warranted, additional crucible scale tests will be performed with "wet" feed prior to the melter run to ensure 
that there are no negative impacts. TFA will also have additional data prior to the melter run that will address whether redox has an effect on the liquidus temperature of DWPF type glasses. These results will be considered prior to the melter run.

\subsection{Sample Splitting and Selection}

The resulting calcined feed will be split into portions suitable for crucible vitrification via an automated sample splitter. An analytical plan will be developed describing the process to be used in obtaining the subsamples. Also included in this plan will be the basis for the chemical analysis of the calcined sludge. The plan will address the need to obtain homogeneous samples (or samples whose measured compositions reveal no statistically significant differences of practical concern) that will ultimately be used in the various crucible scale tests. Samples of the calcined sludge will be submitted and analyzed (by the SRTC Mobile Laboratory (SRTC-ML)) to ensure that the targeted feed composition was attained. Samples of Frit 200 will also be submitted. The analytical plan will accompany these samples to identify the preparation techniques to be utilized, the elements to be analyzed, and the standards to be included.

\subsection{Batch Preparation}

Each batch will be prepared from the proper proportions of calcined sludge (previously split - see Section 2.0) and Frit 200 using GTOP-3-016 [5] as defined in Procedure Manual L 13-1 "Glass Technology Procedures Manual (U)", current revision.[6] Weigh sheets will be filled out as the materiais are weighed and will be maintained as records. The batches produced will be stored in marked containers (poly sample bottle with lid) using their unique nomenclatures.

As previously discussed, model predictions (either internal or external to SRTC) will not be used to target potential waste loadings. This task will approach the waste loading issue independent of model input. The objective of this task is to provide data to determine whether an increase in waste loading is feasible irrespective of model predictions.

This task will evaluate a series of waste loadings from $25 \mathrm{wt} \%$ (current nominal DWPF loading) up to $35 \mathrm{wt} \%$ in $2 \%$ increments (resulting in 6 crucible tests). ${ }^{\mathrm{b}}$ The use of a calcined feed may allow more accurate target loadings and also may minimize the potential for varying feed compositions among the 6 batches due to inhomogeneous mixing in liquid samples.

\subsection{Vitrification}

Prior to vitrification, the calcined sludge and Frit 200 will be mixed by vigorously shaking the poly bottle (with lid). The sludge/frit mixture will then be transferred to a Pt/Rh crucible. Glass melting will be performed according to GTOP-3-017 [7] as defined in Procedure Manual L 13-1 "Glass Technology Procedures Manual (U)", current revision.[6] In general, the batches will be melted in marked $\mathrm{Pt} / \mathrm{Rh}$ crucibles (lids will be used but not sealed as redox issues have been impacted with the calcination of the feed). ${ }^{c}$ The melt regime or thermal history will be recorded in an appropriate laboratory notebook(s). Crucibles will be heated from room temperature up to $1150^{\circ} \mathrm{C}$ (maximum) at approximately $8-10^{\circ} \mathrm{C} / \mathrm{min}$ in a calibrated (profiled) high temperature furnace. The Pt crucibles may be covered ( $\mathrm{Pt}$ lid) during the melting process to minimize volatility. After a 4 hour isothermal hold, the crucible will be removed and the glass poured onto a clean stainless steel quench plate (pour patty produced). Rapidly cooling the glass will minimize the potential for devitrification

\footnotetext{
${ }^{b}$ The current DWPF $T_{L}$ model predicts a 28 wt $\%$ loading without error analysis. When the error analysis is included, the loading is reduced to $25 \mathrm{wt} \%$ to maintain the $\geq 95 \%$ confidence level.

${ }^{c}$ The laboratory tests will be performed using a calcined sludge while the subsequent melter test may be performed using a slurry feed to better simulate the feed to DWPF. Redox issues may differ between the series of tests.
} 
upon cooling. The resulting glass will be stored in an appropriately labeled container and transferred for analysis.

\subsection{Property Measurements}

Homogeneity (a single glass phase)

Each "as-fabricated" glass will be analyzed via optical microscopy and X-ray Diffraction (XRD) for undissolved solids and/or crystallization. If undissolved solids or crystallization are detected, liquidus temperature measurements should not be performed. The sample must be homogeneous prior to the $\mathrm{T}_{\mathrm{L}}$ measurement.

\section{Chemical Composition}

All glass samples will be submitted to the SRTC-ML for chemical analysis via ICP-ES. Select glasses will be supplied to Corning Engineering Laboratory Services (CELS) for chemical analysis. Based on previous results of analytical errors associated with chemical composition measurements, a "signature" oxide(s) will be selected in order to track waste loadings. If possible, an oxide that can be measured accurately (minimum associated error) and is only associated with the waste or feed will be used as the "signature" oxide to determine the waste loading based on chemical composition measurements.

\section{Liquidus Temperature}

Since the objective of this task is to evaluate the liquidus temperature as a function of waste loading, homogeneous glass samples will be submitted for $T_{L}$ measurement (specific techniques described below). SRTC will measure the liquidus temperature of all homogeneous "asfabricated" glasses using both gradient furnace (ASTM C 829-97) and isothermal techniques. The isothermal measurement will be limited to two temperatures and will utilize a "melt back" technique. That is, a sample of the glass will be remelted at $1150^{\circ} \mathrm{C}$ and moved to a prewarmed calibrated furnace at $1050^{\circ} \mathrm{C}$ and left for 24 hours. The resulting sample will be analyzed for the presence or absence of crystallization. This test will only define if the $T_{L}$ is below or above $1050^{\circ} \mathrm{C}$. Another sample (of the same glass) will be remelted at $1150^{\circ} \mathrm{C}$ and moved to a prewarmed, calibrated furnace at $1025^{\circ} \mathrm{C}$ (if the $1050^{\circ} \mathrm{C}$ sample was homogeneous) and left for 24 hours. If the $1050^{\circ} \mathrm{C}, 24$ hour sample contained crystals, the second heat treatment should be performed at $1075^{\circ} \mathrm{C}$. The second sample will be analyzed for crystals as well. The purpose of the isothermal "melt back" tests is to approach $T_{L}$ from above the melt.

Select glasses will be submitted to both Pacific Northwest National Laboratory (PNNL) and Corning Engineering Laboratory Services (CELS) for liquidus temperature measurements using both techniques. Expectations are to send both PNNL and CELS at least three glasses that span the loading range of the homogeneous "as-fabricated" glasses. PNNL and CELS will utilize two techniques to determine $\mathrm{T}_{\mathrm{L}}$ : (1) gradient furnace temperature per ASTM C 829-97 and (2) isothermal melt back tests at $1050^{\circ} \mathrm{C}$ and $1025^{\circ} \mathrm{C}$ (or $1075^{\circ} \mathrm{C}$ ). SRTC will measure the liquidus temperature of all glasses produced.

The following glass characterization tools and controls may be used:

A. Chemical Composition - to be determined by the SRTC Mobile Laboratory (ML) with Inductively Coupled Plasma-Emission Spectroscopy (ICP-ES) and Atomic Absorption (AA) Spectroscopy after appropriate glass dissolution/digestion. SRTC-ML routine analytical procedures will be used. A set of standard glasses will be included as a control and for possible bias correction with every set of glasses analyzed.

B. X-Ray Diffraction - to be performed by Analytical Development Services (ADS) (using routine analytical methods) on ground/crushed glass samples. X-Ray Diffraction (XRD) will be used to 
confirm visual observations of homogeneity and for identification of crystalline phases, if any, after specific heat treatments.

C. Optical microscopy - to be performed, as necessary, on select glass samples. Optical microscopy analysis will be used to determine "gross" crystallization and phase separation/segregation (if encountered).

D. Electron Microscopy - to be performed, as necessary, by ADS on select glass samples. Some glass samples may be submitted for fracture surface analysis to determine secondary phase formation. Glasses susceptible to amorphous phase separation may be analyzed by Transmission Electron Microscopy (TEM), if warranted.

\section{TASK SCHEDULE}

Task

Batch Preparation

Glass Melting

Property Measurement

Data Reduction

Report
Completion Date

$3 / 30 / 99$

$4 / 15 / 99$

$5 / 15 / 99$

$5 / 20 / 99$

$5 / 30 / 99$

\section{RESEARCh FACILITY PLANNING}

No by-products will be generated in this task that are not covered by the current waste management and disposal procedures. The test equipment utilized will be maintained during the testing program and the appropriate standards will be used where applicable. All applicable sections of the WSRC Safety Manual [8] will be followed. The safety sections of each procedure employed will be followed.

VI. Programmatic Risk AsSessment

A programmatic risk assessment for each subtask will be performed per Procedure 7.10, L1 Manual. This assessment is the responsibility of the subtask leaders as identified in Section I, C.

\section{R\&D HAZARDS SCREENING CheCKLIST}

Per Chapter 3 of SRTC Conduct of R\&D Manual, each subtask leader will perform the appropriate R\&D Hazards Screening Checklist. 


\section{REFERENCES}

1. J.R. Zamecnik and C.M. Jantzen, Test Plan - Liquidus Temperature and Phase Separation Validation of Liquidus Temperature Model in a Small Melter, WSRC-TR-98-DRAFT, November 1998.

2. Tanks Focus Area Technical Task Plan, SR1-6-WT-31, Task A.2-1, Optimized Waste Loading.

3. WSRC 1Q Quality Assurance Manual, QAP 2-3, Control of Research and Development Activities (1998).

4. Conduct of Research \& Development Savannah River Technology Center (U), WSRCIM-97-00024, Rev. 1, November 1998.

5. Laboratory Scale Glass Preparation Procedure, GTOP-3-016, Procedure Manual L 131, Savannah River Technology Center, Glass Technology Manual.

6. Glass Technology Procedures Manual (U), Procedure Manual L 13-1, Westinghouse Savannah River Company, 1998.

7. Laboratory Scale Glass Melting Procedure, GTOP-3-017, Procedure Manual L 13-1, Savannah River Technology Center, Glass Technology Manual.

8. Employee Safety Manual, 8Q, (1997).

\section{QA Plan Checklist}

The following QA Procedures apply for this task (indicate Yes, No or "AR" - as required). Current revision of the procedure will be used.

\begin{tabular}{|l|l|l|l|}
\hline Yes & No & AR & \\
\hline & & & 1.1 ORGANIZATION \\
\hline $\mathbf{X}$ & & & 1Q, QAP 1-1, Organization \\
\hline & & & L1, 1.02, SRTC Organization \\
\hline & & & \\
\hline & & $\mathbf{X}$ & $\mathbf{1 - 2}$ STOP WORK \\
\hline & & & \\
\hline & & & $\mathbf{2 - 1}$ QUALITY ASSURANCE PROGRAM \\
\hline $\mathbf{X}$ & & & $1 \mathrm{Q}$, QAP 2-1, Quality Assurance Program \\
\hline $\mathbf{X}$ & & & L1,8.01, SRTC QA Program Implementation \\
\hline & & & L1,8.02, SRTC QA Program Clarifications, Attachment 6 \\
\hline & & & $\mathbf{2 - 2}$ PERSONNEL TRAINING \& QUALIFICATION \\
\hline $\mathbf{X}$ & & & $1 \mathrm{Q}$, QAP 2-2, Personnel Training \& Qualification \\
\hline $\mathbf{X}$ & & & L1, 5.01, SRTC Training, Orientation \& Employee Development \\
\hline $\mathbf{X}$ & & & L1, 1.32, Read and Sign \\
\hline & & & \\
\hline & & & $\mathbf{2 - 3}$ CONTROL OF RESEARCH \& DEVELOPMENT ACTIVITIES \\
\hline $\mathbf{X}$ & & & $1 \mathrm{Q}$, QAP 2-3, Control of Research \& Development Activities \\
\hline $\mathbf{X}$ & & & L1, 8.02, SRTC QA Program Clarifications, Attachment 1 \\
\hline $\mathbf{X}$ & & & L1, 7.10, Control of Technical Work \\
\hline & & & \\
\hline & $\mathbf{X}$ & & $\mathbf{2 - 4}$ AUDITOR/LEAD AUDITOR QUALIFICATION \& CERTIFICATION - \\
\hline
\end{tabular}




\begin{tabular}{|c|c|c|c|}
\hline Yes & No & $\mathbf{A R}$ & \\
\hline & & & does not apply to Immobilization Technology Section Tasks \\
\hline & & & \\
\hline & $\mathbf{X}$ & & $\begin{array}{l}\text { 2-5 QUALIFICATION \& CERTIFICATION OF INDEPENDENT } \\
\text { INSPECTION PERSONNEL - does not apply to Immobilization Technology } \\
\text { Section Tasks }\end{array}$ \\
\hline & & & \\
\hline & $\mathbf{X}$ & & $\begin{array}{l}\text { 2-6 QA MANUAL REVISION - does not apply to Immobilization Technology } \\
\text { Section Tasks }\end{array}$ \\
\hline & & & \\
\hline & & & $\begin{array}{l}\text { 2-7 QA PROGRAM REQUIREMENTS FOR ANALYTICAL } \\
\text { MEASUREMENT SYSTEMS }\end{array}$ \\
\hline & & $\mathbf{X}$ & 1Q, QAP 2-7, QA Program Requirements for Analytical Measurement Systems \\
\hline & & & \\
\hline & $\mathbf{X}$ & & $\begin{array}{l}\text { 2-10 INDEPENDENT INSPECTION PERSONNEL ON-THE-JOB TRAINING } \\
\text { - does not apply to Immobilization Technology Section }\end{array}$ \\
\hline & & & \\
\hline & & & 3.1 DESIGN CONTROL \\
\hline & $\mathbf{X}$ & & 1Q, QAP 3-1, Design Control \\
\hline & $\mathbf{x}$ & & $\mathrm{L} 1,7.10$, Control of Technical Work \\
\hline & & & \\
\hline & & & 4-1 PROCUREMENT DOCUMENT CONTROL \\
\hline & & $\mathbf{X}$ & 1Q, QAP 4-1, Procurement Document Control \\
\hline & & $\mathbf{X}$ & L1, 8.02, SRTC QA Program Clarifications, Attachment 2 \\
\hline & & & \\
\hline & & & 5-1 INSTRUCTIONS, PROCEDURES \& DRAWINGS \\
\hline $\mathbf{X}$ & & & 1Q, QAP 5-1, Instructions, Procedures \& Drawings \\
\hline & $\mathbf{X}$ & & E7, 2.30, Drawings \\
\hline$\overline{\mathbf{X}}$ & & & L1, 1.01, SRTC Procedure Administration \\
\hline & & $\mathbf{X}$ & L1, 1.01.1, SRTC Work Instructions \\
\hline & & & \\
\hline & & & 6-1 DOCUMENT CONTROL \\
\hline $\mathbf{X}$ & & & 1Q, QAP 6-1, Document Control \\
\hline$\overline{\mathbf{X}}$ & & & L1, 1.30, SRTC Document Control \\
\hline & & & \\
\hline & & & 7-2 CONTROL OF PURCHASED ITEMS \& SERVICES \\
\hline & & $\mathbf{X}$ & 1Q, QAP 7-2, Control of Purchased Items \& Services \\
\hline & & & \\
\hline & & & $\begin{array}{l}\text { 7-3 COMMERCIAL GRADE ITEM DEDICATION AND MATERIAL } \\
\text { UPGRADE }\end{array}$ \\
\hline & $\mathbf{X}$ & & 1Q, QAP 7-3, Commercial Grade Item Dedication \& Material Upgrade \\
\hline & $\mathbf{X}$ & & E7, 3.46, Replacement Item Evaluation/Commercial Grade Item Dedication \\
\hline & & & \\
\hline & & & 8-1 IDENTIFICATION \& CONTROL OF ITEMS \\
\hline & & $\mathbf{X}$ & 1Q, QAP 8-1, Identification \& Control of Items \\
\hline & & $\mathbf{X}$ & L1, 8.02, SRTC QA Program Clarifications, Attachment 7 \\
\hline & & & \\
\hline & $\mathbf{X}$ & & $\begin{array}{l}\text { 9-1 CONTROL OF PROCESSES - does not apply to Immobilization } \\
\text { Technology Section Tasks }\end{array}$ \\
\hline & & & \\
\hline
\end{tabular}




\begin{tabular}{|c|c|c|c|}
\hline \multirow{2}{*}{ Yes } & \multirow{2}{*}{$\frac{\text { No }}{\mathrm{X}}$} & \multirow{2}{*}{$\mathbf{A R}$} & \multirow[b]{2}{*}{$\begin{array}{l}\text { 9-2 CONTROL OF NONDESTRUCTIVE EXAMINATION - does not apply to } \\
\text { Immobilization Technology Section Tasks }\end{array}$} \\
\hline & & & \\
\hline & $\mathbf{X}$ & & $\begin{array}{l}\text { 9-3 CONTROL OF WELDING \& OTHER JOINING PROCESSES - does not } \\
\text { apply to Immobilization Technology Section Tasks }\end{array}$ \\
\hline & & & \\
\hline & $\mathbf{X}$ & & $\begin{array}{l}\text { 9-4 WORK CONTROL - does not apply to Immobilization Technology Section } \\
\text { Tasks }\end{array}$ \\
\hline & & & \\
\hline & & & 10-1 INSPECTION \& VERIFICATION \\
\hline & $\mathbf{X}$ & & 1Q, QAP 10-1, Inspection \& Verification \\
\hline & $\mathbf{X}$ & & L1, 8.10, Inspection \\
\hline & $\mathbf{X}$ & & L1, 8.10.1, Independent Inspection Releases \\
\hline & & & \\
\hline & & & 11-1 TEST CONTROL \\
\hline & $\mathbf{X}$ & & 1Q, QAP 11-1, Test Control \\
\hline & & & \\
\hline & & & 12-1 CONTROL OF MEASURING \& TEST EQUIPMENT \\
\hline $\mathbf{X}$ & & & 1Q, QAP 12-1, Control of Measuring \& Test Equipment \\
\hline & & & \\
\hline & & & 12-2 CONTROL OF INSTALLED PROCESS INSTRUMENTATION \\
\hline & $\mathbf{X}$ & & 1Q, QAP 12-2, Control of Installed Process Instrumentation \\
\hline & & & \\
\hline & $\mathbf{x}$ & & $\begin{array}{l}12-3 \text { CONTROL \& CALIBRATION OF RADIATION MONITORING } \\
\text { EQUIPMENT - does not apply to Immobilization Technology Section Tasks }\end{array}$ \\
\hline & & & \\
\hline & & & 13-1 PACKAGING, HANDLING, SHIPPING \& STORAGE \\
\hline & $\mathbf{X}$ & & 1Q, QAP 13-1, Packaging, Handling, Shipping \& Storage \\
\hline & $\mathbf{X}$ & & L1, 8.02, SRTC QA Program Clarifications, Attachment 9 \\
\hline & & & 14-1 INSPECTION, TEST \& OPERATING STATUS \\
\hline & & $\mathbf{X}$ & 1Q, QAP 14-1, Inspection, Test \& Operating Status \\
\hline & & $\mathbf{X}$ & L1, 8.02, SRTC QA Program Clarifications, Attachment 3 \\
\hline & & & \\
\hline & & & 15-1 CONTROL OF NONCONFORMING ITEMS \\
\hline & & $\mathbf{X}$ & 1Q, QAP 15-1, Control of Nonconforming Items \\
\hline & & $\mathbf{X}$ & $\mathrm{L} 1,8.02$, SRTC QA Program Clarifications, Attachment 4 \\
\hline & & & \\
\hline & & & 15-2 CONTROL OF NONCONFORMING ACTIVITIES \\
\hline & & $\mathbf{X}$ & 1Q, QAP 15-2, Control of Nonconforming Activities \\
\hline & & $\mathbf{X}$ & L1, 8.02, SRTC QA Program Clarifications, Attachment 10 \\
\hline & & & \\
\hline & & & 16-1 CORRECTIVE ACTION SYSTEM \\
\hline & & $\mathbf{X}$ & 1Q, QAP 16-1, Corrective Action System \\
\hline & $\mathbf{x}$ & & $\begin{array}{l}\text { 16-2 QUALITY ALERT - does not apply to Immobilization Technology Section } \\
\text { Tasks }\end{array}$ \\
\hline & & & \\
\hline & & & 17-1 QA RECORDS MANAGEMENT \\
\hline
\end{tabular}




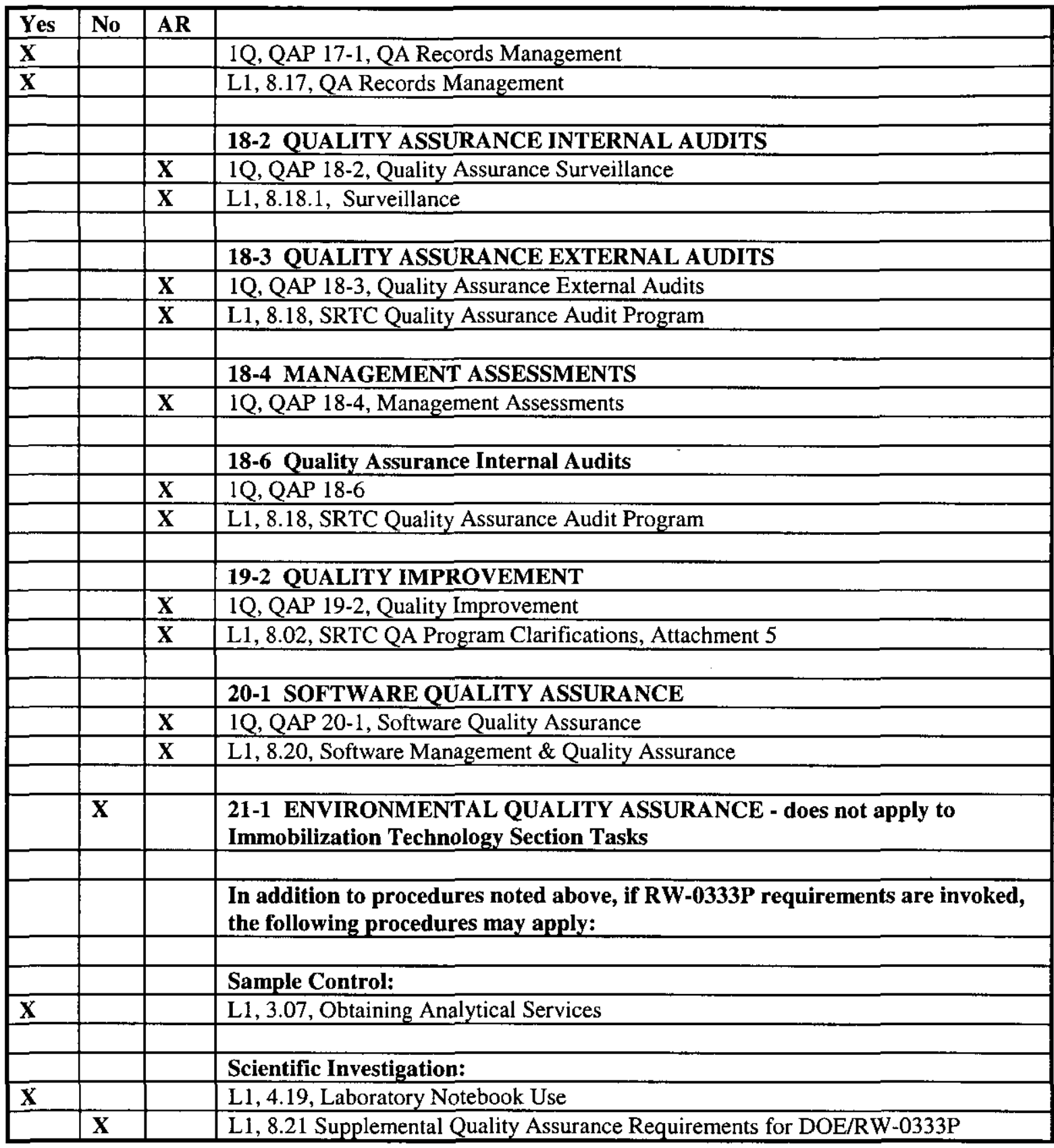

VIII. Identify any exceptions or additions to the procedures listed in the QA Matrix:

This task is not being performed according to Quality Assurance Criteria as defined by RW-0333P.

IX. Complete this part only if Section 20 procedures (software) are invoked. Identify who will act in each of the following capacities. N/A

Owner: N/A

Designer: N/A

Maintainer: N/A

Tester: N/A 


\section{Document Approval:}

Identify documents requiring management, customer or CQF approval

\begin{tabular}{|c|c|c|c|}
\hline Document & Management & Customer & $\mathrm{CQF}$ \\
\hline & Yes & Yes & Yes \\
\hline Technical \& QA Plan & $\mathrm{X}$ & $\mathrm{X}$ & $\mathrm{X}$ \\
\hline Final Report & $\bar{X}$ & $\bar{X}$ & $\mathrm{X}$ \\
\hline
\end{tabular}

\section{Anticipated Records:}

The following records are anticipated from this task. Indicate Yes, No or AR (as required):

\begin{tabular}{|l|l|l|l|}
\hline Yes & No & AR & \\
\hline & & & \\
\hline $\mathrm{X}$ & & & Task Technical \& QA Plan \\
\hline $\mathrm{X}$ & & & Technical Notebooks \\
\hline & & $\mathrm{X}$ & Task Technical Reports \\
\hline & $\mathrm{X}$ & & Data Qualification Reports \\
\hline & & $\mathrm{X}$ & Supporting Documentation \\
\hline
\end{tabular}

Any additional comments: None 
Title

An Evaluation of Liqiudus TEmperature as a Function of Waste Loading for a Tank 42 "Sludge Only" / Frit 200 Flowsheet (U)

\begin{tabular}{|c|c|c|c|c|}
\hline $\begin{array}{l}\text { Primary Author/Contact (Must be WSRC) } \\
\text { David Peeler }\end{array}$ & $\begin{array}{l}\text { Location } \\
773-43 \mathrm{~A} \\
\end{array}$ & $\begin{array}{l}\text { Phone No. } \\
5-0623\end{array}$ & $\begin{array}{l}\text { Position } \\
\text { Senior Research Sci. }\end{array}$ & $\begin{array}{l}\text { User ID } \\
\text { L6814 }\end{array}$ \\
\hline $\begin{array}{l}\text { Organization Code } \\
\text { L3100 }\end{array}$ & \multicolumn{4}{|c|}{ Organization (No Abbreviations) } \\
\hline $\begin{array}{l}\text { Other Authors } \\
\text { D.P. Lambert, J.R. Zamecnik, W.E. De }\end{array}$ & $\mathrm{el}$, and T.B & & $\begin{array}{l}\text { Deadline Date } \\
\text { 4/30<99 }\end{array}$ & $\begin{array}{l}\text { Appro } \\
28\end{array}$ \\
\hline
\end{tabular}

Has an invention disclosure been submitted related to this information?

$\square$ res $\bigotimes$ No

Disclosure No. (If Known)_ Title___ Date Submitted

Do you intend to submit an invention disclosure? $\square$ Yes $\square$ No If yes, projected date

\begin{tabular}{l|l} 
Information Product Description & Conference/Meeting/Presentation
\end{tabular}

$\begin{array}{ll}\text { ¿report Type } & \text { Meeting Title (No Abbreviations) }\end{array}$

$\square$ Quarterly $\square$ Annual $\square$ Final $\square$ Other

$\square$ Semiannual $\bigotimes$ Technical [TTopical

Report Dates__ thru___

$\square$ Conference Type

$\square$ Abstract $\square$ Published Proceedings

$\square$ Cont Paper

$\square$ Other

$\square$ Slides

$\square$ Journal Article (Journal Name)

$\square$ Videotape/Multimedia

External Web Page

$\square$ Software (Additional forms are required (ESTSC F1 and F2)).

References \In Public Literature $\square$ Routing Concurrently Sponsor

$\square$ Approved for Release Xother NDT CoTt-Reprtable

I understand that for the information in this material to be given external disbribution, approvals by both WSAC and, as appropriate, DOE-SR are required. Distribution (verbally or published) must be in agperdance with policies set forth in WSRC management requirements and procedures (MRP 3.25) and in DOE-SR orders, and the content of the external distribution nust be lingled tha factually approved.

Nolus

$(\mathrm{m} / \mathrm{d} / \mathrm{y})$ thru

$(\mathrm{m} / \mathrm{d} / \mathrm{y})$

\section{Approvals by Author's Organization}

\begin{tabular}{|l|l|l|l|}
\hline Derivative Classitier & Topic & Distribution & Classification \\
\hline Explanations & 4 & Unlimited $\square$ Limited (Explain Below) \\
\hline
\end{tabular}

I understand and have considered whether any potential intellectual property rights (patents, copyrights, etc., in accordance with MP 1.09 and MRP 1.07) or any contractural barriers (CRADAs, Work for Others, etc.) may be involved before authorizing that this document be proposed for public release. If any concerns were identified, these have been discussed and resolved with Ganeral founsel

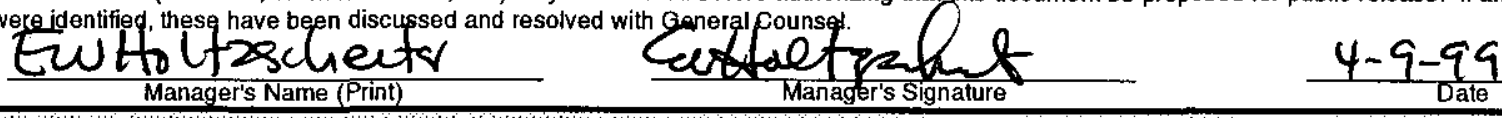

Classification Intormation (To be completed by Classification Reviewer)

Classification (Check One for Each)

Overall

Abstract

\begin{tabular}{ll}
$\square$ s \\
$\square$ s \\
$\square$ s \\
\hline c \\
\hline c
\end{tabular}

$\square$ UCNI

$\square$ UCNI

Vy

Title

$\square$ UCN

Classification Guide Topics

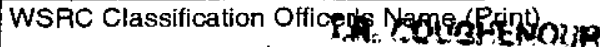
ansirication anayes

wsrgyosifigaton Officer's Signature

Yh. Crequhree
$4-26-99$

Export Control Roview 1 o be Completed by Export Control Reviewing Otficial)

Export Control Related

Wres $\quad$ No

Export Control Reviewer's Name (Print)

I. A. TOLGHENOIN

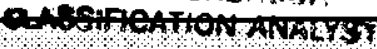

UC/C Numbe

$\mathrm{OS}$

COass/LC/DOE Exportgintroviewtris Signature STI Program Use Only

NOTE OSR 17-8 must be completed in addition to this form when submitting information for review and approval. Keqperads: ser Diconds form 
Ms. W. F. Perrin, Technical Information Officer

U. S. Department of Energy - Savannah River Operations Office

Dear Ms. Perrin:

\section{REQUEST FOR APPROVAL TO RELEASE SCIENTIFIC/TECHNICAL INFORMATION}

The attached document is submitted for classification and technical approvals for the purpose of external release. Please complete Part II of this letter and return the letter to the undersigned by 5/28/99. The document has been reviewed for classification and export control by a WSRC Classification staff member and has been determined to be Unclassified.

\section{DETAILS OF REQUEST FOR RELEASE}

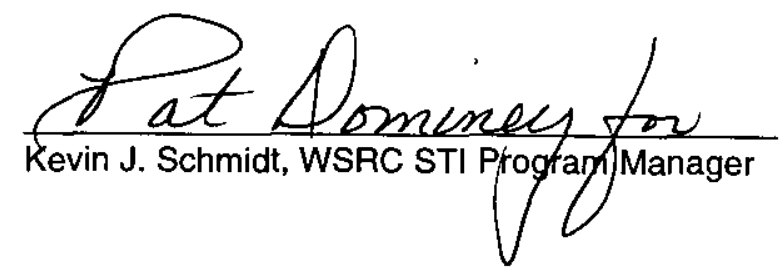

Document Number: WSRC-RP-99-00253, Rev. 0

Author's Name: D. Peeler

Location: 773-43A

Phone 5-0623

Department: Immobilization Technology Section

Document Title: An Evaluation of Liquidus Temperature as a Function of Waste Loading for a Tank 42 "Sludge Only"/Frit 200 Flowsheet

Presentation/Publication:

Meeting/Journal:

Location:

D\&TI

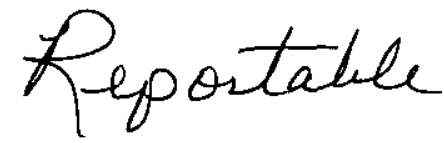

Meeting Date:

\section{DOE-SR ACTION}

\section{Date Received by TIO}

$04 / 27 / 99$

X Approved for Release

$\square$ Approved Upon Completion of Changes

Approved with Remarks

Remarks:

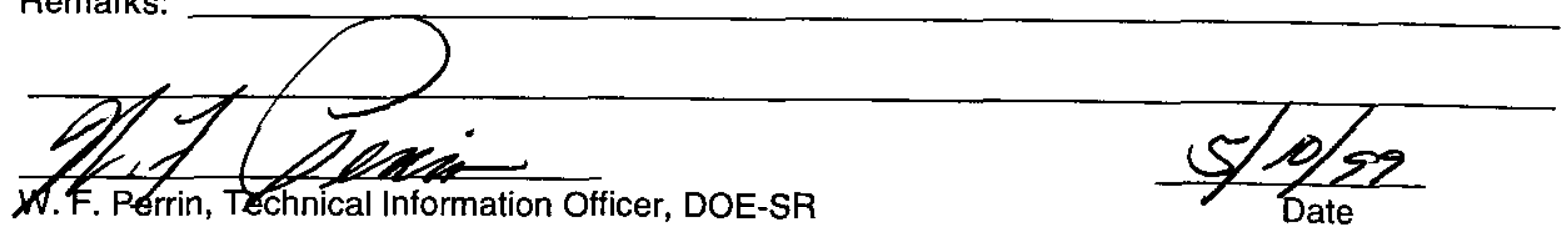


RECORD STATUS (select one):

X..New .......Revised Data .... Zevised STI Product

Part I: STI PRODUCT DESCRIPTION

A. STI PRODUCT TYPE (select one)

X.. 1. Technical Report
a. Type:
$\square$ Topical $\square$ semiannual
$\square$ Annual $\square$ Final
b. Reporting Period $(\mathrm{mm} / \mathrm{dd} / \mathrm{y} y \mathrm{y} y$,
thru
Other (specify)

2. Conference
a. Product Type: ....... Conference Proceedings

b. Conference Information (title, location, dates)

3. Software Manual ( The actual sothware package should be made available simultaneously. Follow instructions provided with ESTSC F 1 and ESTSC F 2.)

..... 4. Journal Article
a. Type: $\quad X$ Announcement citation only
_. Preprint
Postprint
b. Journal Name
c. Volume
d. Issue
e. Serial identifier (e.g., ISSN or CODEN)

5. S\&T Accomplishment Report

6. Book

7. Patent Application

a. Date Filed $(\mathrm{mm} / \mathrm{dd} / \mathrm{y} y \mathrm{y})$

b. Date Priority $(\mathrm{mm} / \mathrm{dd} / \mathrm{y} y \mathrm{y} y)$

c. Patent Assignee

.... 8. Thesis/Dissertation

B. STI PRODUCT tITLE .An.Fval.uation.of.Li.quidus.Temperature.as.a.F.ungtion.of..Waste..Loading.fox.a.T.ank.42...Sludge.........

C. AUTHOR(s) D...... _...eeler.

E-mail Address(es):

D. STI PRODUCT IDENTIFIER

1. Report Number(s) WSRC-RP.:-99-0.0253.Rex.

2. DOE Contract Number(s) DE-AC09-96SR18500

3. R\&D Project ID(s)

4. Other Identifying Number(s)

E. ORIGINATING RESEARCH ORGANIZATION Savannah River Site

F. DATE OF PUBLICATION ( $\mathrm{mm} / \mathrm{dd} / \mathrm{y} y \mathrm{y} y)$

G. LANGUAGE (if non-English) English

(Grantees and Awardees: Skip to Description/Abstract section at the end of Part )

H. SPONSORING ORGANIZATION

I. PUBLISHER NAME AND LOCATION (if other than research organization)

Availability (refer requests to [if applicable])

J. SUBJECT CATEGORIES (list primary one first) $\quad 0.5$

Keywords .Tank.42..DWP......Waste..Loading.

K. DESCRIPTION/ABSTRACT

The waste glass produced in the SRS Defense Waste Processing Faiclity (DWPF) process must comply with Waste Acceptance Product Specifications (WAPS) and process control requirements by demonstrating, to a high degree of confidence, that melter feed will produce glass satisfying all quality and processing requirements. 
Part II: STI PRODUCT MEDIAFORMAT and LOCATION/TRANSMISSION

A. MEDIA/FORMAT INFORMATION
1. Medium of STI product is:
X.. Paper
....... Electronic document
...... Computer medium
..... Audiovisual material

2. Size of STI product

3. File format:

a. If electronic document is posted at site, indicate: $\square$ html $\square$ pdfn $\square$ sgml $\square$ xml

b. If electronic document is transmitted to OSTI, indicate: $\square$ html $\square$ pdfn $\square$ pdfi $\square$ msword _TIFFG4 _-WP-indicate Version (5.0 or greater) _MS Word-indicate Version (5.0 or greater) platform/operating system

4. If computer medium or audiovisual material:

a. Quantity/type (specify)

b. Machine compatibility (specify)

c. Sound:

f. Other information about product format a user needs to know:

\section{B. LOCATION/TRANSMISSION INFORMATION}

1. STI Product is available at site: Unique URL (of specific STI Product)

2. STI Product is being transmitted to OSTI:

a.__ Electronically via FTP

b._. Via Mail or shipment (e.g., Federal Express) (Paper products, electronic documents on CD-ROM, diskettes, videocassettes, etc.)

3. Information Product Filename (of transmitted electronic format)

C. ADDITIONAL INFORMATION (concerning media/format or location/transmission; for OSTI internal use only):

(Grantees and Awardees: Skip to Contact section at the end of Part III)

Part III: STI PRODUCT REVIEW? RELEASE INFORMATION

A. ACCESS LIMITATION

X..... 1. Unlimited Announcement (available to U.S. and non-U.S. public)

........ 2. OpenNet (use OpenNet guidance for below):

a. If additional source other than making it available through NTIS:

(1) Accession Number

(2) Document Location

b. Field Office Acronym

c. Declassification date (mm/dd/yyyy)

d. Declassification Status:

Declassified _ Sanitized _- Never classified

3. U.S. Dissemination Only

4. Copyrighted material; Are there any restrictions based on copyright?

e. OpenNet Document Type

f. OpenNet Document Keywords

g. OpenNet Addressee
5. Small Business Innovation Research $(S B I R)$ Release date ( $\mathrm{mm} / \mathrm{dd} / \mathrm{yyy} y$ )
6. Small Business Technology Transfer (STTR) Release date ( $\mathrm{mm} / \mathrm{dd} / \mathrm{yyyy}$ )
7. Proprietary/Trade Secret
8. Patent Pending
9. Protected data CRADA Other (specify) Release date (mm/dd/yyyy)

10. Official Use Only (OUO)

11. Program-Directed Special Handling (specify)

12. Export ControUTTAR/EAR

13. Unclassified Controlled Nuclear Information (UCNI)

14. Classified Classification Level/Categorv of:

a. This form $\mathbf{U}$.

b. The STI Product Unclassified

15. Other information relevant to access (specify; for OSTI intemal use only))

B. OTHER (information useful to include in published announcement record which is not suited for any other field on this form)

\section{CONTACT AND RELEASING OFFICIAL}

1.Contact (if appropriate, the organization or site contact to include in published citations who would receive any extemal questions about the content of the STI Product or the research information contained therein

Name and/or Position K.J. Schmidt, Manager STI Program \& Site Support

E-mail

Organization Westinghouse Savannah River Company Phone (803) 725-2321

2. Releasing Official $\mathbf{X}$ I verify that all necessary reviews have been completed (e.g. Patent, Copyright, ECI, UCNI, etc.)

Released by (name) K.J. Schmidt Date (mm/dd/yyyy) E-Mail

Phone 